Revista do CESP, Belo Horizonte, v.37, n.57, p. 137-139, 2017

\title{
LOSA, Margarida. Do romance realista ao romance proletário. Lisboa: Campo da Comunicação, 2014. 278 p.
}

Patrícia Resende Pereira

Universidade Federal de Minas Gerais, Belo Horizonte, Minas Gerais Brasil patriciarpereira@gmail.com

Recebido em 4 de junho de 2017 Aprovado 6 de julho de 2017

Polêmico, o movimento neo-realista ganha das mãos da pesquisadora Margarida Losa um amplo estudo, que investiga a literatura portuguesa, italiana e brasileira, no livro Do romance realista ao romance proletário. Resultado de sua tese de doutorado, produzida na década de 1970 na Universidade de Nova York, a pesquisa foi publicada pela editora Campo da Comunicação em 2014, em uma parceria entre o Museu do Neo-realismo e o Instituto de Literatura Comparada Margarida Losa, fundado pela autora quando lecionava na Universidade do Porto.

Antes de iniciar a leitura dos capítulos da tese, de 278 páginas, é interessante conferir o texto introdutório, no qual Losa justifica a escolha do neo-realismo como tema de sua pesquisa. Era, então, a época em que a pesquisadora tinha o intuito de morar no exterior, longe da Europa, e nutria o desejo de manter contato com a literatura de sua terra natal. Soma-se a isso o fato de que, como é explicado por ela, o "neo-realismo parecia-me uma opção produtiva uma vez que eu estivera envolvida na polémica que rodeava o movimento, desde os meus tempos de liceu e de faculdade, em Portugal". (LOSA, 2014, p. 11).

É nessa parte que o leitor conhece a justificativa do recorte proposto pela autora: caracterizar o romance neo-realista publicado entre 
1930 e 1955 no Brasil, na Itália e em Portugal. Os dois últimos países foram escolhidos porque são onde o movimento adotou especificamente tal termo para designá-lo. Já o Brasil foi selecionado em razão da influência exercida pela nossa literatura no neo-realismo português, embora aqui ganhe o nome de movimento nordestino. Portanto, não se usa o mesmo termo em todos os lugares, o que leva a autora a optar por novo realismo social para se referir a ele.

O livro é dividido em duas partes, cada uma com três longos capítulos. O primeiro deles, intitulado "Realismo literário: uma introdução à teoria", tem o intuito de fazer um percurso histórico para explicar as características do movimento, iniciando em Aristóteles e sua discussão acerca da mimese. Logo depois, tem-se uma esclarecedora reflexão acerca da forma, do sentido e do conteúdo do novo realismo social, além dos métodos necessários para pensá-lo. Apesar de breve, este primeiro capítulo cumpre bem a função de fornecer subsídios para que o leitor tenha condições de acompanhar a análise.

Posteriormente, em "O cânone realista e o romance do novo realismo social", segundo capítulo, Losa continua a sua discussão teórica acerca do novo realismo social, agora com a proposta de se pensar nas características idealistas e românticas. A autora explica que o termo "romântico", empregado ao longo de toda a tese, refere-se à forma adjetiva de romance, informação importante para a compreensão de seu trabalho. É também nessa parte que se pensa nas características estruturais da narrativa a ser investigada, como a maneira como o herói é apresentada, a narração, a construção do enredo, o sentido do texto, entre outros elementos que tornam possível a discussão proposta.

Por fim, no terceiro capítulo, que recebe o título "Uma genealogia romanesca do romance do novo realismo social", a pesquisadora continua a pensar na teoria e no método que deverão ser ponto de partida para a discussão proposta. Para tanto, ainda com base na discussão iniciada na seção anterior, Losa define ação, narração e significação como pontos centrais para se pensar os pontos românticos do romance neo-realista, verificados a partir do século XIX.

Logo depois do longo percurso teórico, a autora inicia, na segunda parte, a análise das obras literárias selecionadas. No primeiro capítulo da nova seção, intitulado "A emergência do novo realismo social em Itália, no Brasil e em Portugal”, há a apresentação do contexto em que 
as obras analisadas foram publicadas, além de uma discussão sobre o modernismo e o naturalismo.

É importante enfatizar que, no referido capítulo, a estudiosa apresenta os quatro autores essenciais para a pesquisa: Jorge Amado, Alves Redol, de Portugal, Vasco Pratolini, da Itália, e o norte-americano John Steinbeck e seu clássico As vinhas da ira. A justificativa para a seleção é bastante simples. Os quatro autores são considerados por Losa como os mais representativos do que é chamado por ela de novo realismo social.

Com essa informação em mente, em "Heróis positivos e conversões místicas: o percurso ascendente do romance do novo realismo social", o segundo capítulo, a autora faz uma reflexão tendo a classe operária como ponto de partida. É preciso enfatizar que a recepção do leitor também é objeto de discussão nessa parte, como comprova a segunda seção, intitulada "Da conversão do herói à conversão do leitor".

No último capítulo, "A fuga ao real: o pastoral e o melodramático", Losa faz uma análise mais detalhada de Jubiabá, de Jorge Amado, Avieiros, de Redol, Cronache di poveri amanti, de Pratolini, e In dubious battle, de Steinbeck. A investigação mais aprofundada cumpre a função de se pensar a maneira como as batalhas sociais são apresentadas em cada um deles.

Assim sendo, em sua tese de doutorado, agora transformada em livro, Losa propõe um rico percurso ao longo do neo-realismo da primeira metade do século XX. Temos, portanto, uma obra capaz de ajudar a pensar o movimento literário, mesmo hoje assunto polêmico de discussão. 